\title{
Coastal disaster mitigation through shoreline changes analysis in Pariaman city
}

\author{
Azria Paldi Donal ${ }^{1 *}$ and Andriani $^{2}$ \\ ${ }^{1}$ Magister Program, Civil Engineering Department, Faculty of Engineering Andalas University, Padang, Indonesia \\ ${ }^{2}$ Civil Engineering Department, Faculty of Engineering Andalas University, Padang, Indonesia
}

\begin{abstract}
Disasters caused losses and damage to the coastal areas of Pariaman City. The construction costs for development in coastal areas are relatively expensive. Early good research must be done to monitor shoreline changes and reduce losses and damage in the coastal areas of Pariaman City. The method used to monitor shoreline changes using satellite images with GIS techniques. The coastal change analyzes is studied including coastal erosion and sedimentation. In this study, disaster mitigation and impacts reduction caused by coastal changes are the final purposes. The losses and damage due to coastal changes were monitored during a certain time. The results of this study are aimed to make a solution for disaster mitigation in coastal areas caused by the shoreline changes in Pariaman City.
\end{abstract}

\section{Introducing}

Yasumoto, et al (2007) [1] study on Tottori Beach, Japan which has a coastline of $129 \mathrm{~km}$. Beaches experience increasingly severe erosion and sedimentation that disrupts navigation in the port. The study was conducted to reduce/control coastal erosion and sedimentation that occurred on the coast of Tottori, Japan. This study investigated shoreline changes using aerial photographs taken from 1947 to 2003, field observations in 2005 and bathymetry survey data in 1987 and 2003. From the research, it was concluded that sediment transport was induced from the Tottori dune to the Tottori port caused by influence port breakwater. It is recommended that there is no more offshore sand removal, no more dredging offshore sand for reclamation, and sand dredged from the accretion/accumulation zone must be disposed of on the lower coast.

Sri Lanka has a coastline that reaches $1600 \mathrm{Km}$ and there is an increase in coastal erosion and environmental damage, especially on Unawatuna Beach. This study analyzes the causes and effects of coastal erosion that occurred on the Unawatuna coast. The method used by comparing images from Google Earth uses the Arc GIS 9.3 application in 2007, 2009, 2011, 2013 and 2015. Based on research, the high socio-economic activity in Unawatuna plays an important role in increasing coastal erosion. Although coastal protection has been carried out with breakwater erosion still occurs. It is therefore recommended that green hotels and green belts be used as well as conducting an environmental impact assessment survey before carrying out development. This study has data on erosion and coastal damage that occurred from 2007 to 2015. (Senevirathna et al, 2018) [2].
Rangel-Buitrago et al (2015) [3] which aims to determine the magnitude of erosion that occurs, the causes of erosion and regulation on Carribean Beach, Colombia. The method used to identify shoreline changes using aerial photography and evaluating shoreline changes using End Point Rate (EPR) and Linear Regression (LRR). This study has a good data presentation. This study shows that $48.3 \%(1182 \mathrm{Km})$ of the Caribbean Coast, Colombia has experienced high erosion, the main cause of which is natural factors such as the sea-level rise and extreme waves.

Kankara et al (2015) [4] conducted a study aimed at monitoring changes in the shoreline that occurred on the coast of Andhra Pradesh with a beach length of $974 \mathrm{Km}$. The method used to monitor shoreline changes using satellite imagery and to calculate the level of shoreline change used Digital Shoreline Analysis System (DSAS) version 4.0 and ESRI ArcGIS. Based on a long-term analysis of shoreline changes showed that $275 \mathrm{~km}$ of the Andhra Pradesh coast experienced erosion. Short-term analysis from 1990-2000 showed $36.39 \%$ of the coastal erosion, in 2000-2006 there was an erosion of $42 \%$ and in 2006-2012 the coastal erosion of $44.76 \%$.

Shandong has $3.345 \mathrm{~km}$ of coastline and more than $1200 \mathrm{~km}$ of the Shandong coast has serious erosion. It is hoped that through this research a better solution in erosion management on the shore of Shandong. The method carried out by calculating the amount of erosion that occurred on the shore of Shandong and its causes, calculated the sediment load from the main rivers in Shandong and the coastal protection that had been carried out along the shore of Shandong. Protection using seawalls, groins, jetties, and breakwaters has been carried out to protect coastal erosion but doesn't reduce/change the causes of erosion. A combination of

\footnotetext{
* Corresponding author: azriapaldi@gmail.com
} 
hard and soft approaches such as coastal nourishment is needed to deal with the effects of long-term erosion (Yina et al, 2018) [5].

Buchori et al, 2018 [6] which aims to understand and know the mitigation efforts and local migration patterns of Semarang City residents due to tidal flooding. The methods used are the quantitative methods, data, and information obtained by field observation, questionnaire, interview, and documentary review. From this study, it was concluded that the population had made structural mitigation efforts such as raising their buildings or houses. Residents prefer to survive and adapt to the danger of rob rather than move/leave their homes. Recommendations submitted to the Regional Government in rob hazard mitigation are only efforts to evaluate and revise the city's spatial plan that can be done every five years

Various actions have been taken to fight coastal erosion such as hard protection (hold /advance the line), accommodation, managed retreat, and sacrifice. The method is carried out by analyzing the causes and measures of protection against erosion and shoreline management. From several measures for protection against erosion, this paper emphasizes the option of sacrifice (sacrifice) in the management of coastal erosion (Williams et al, 2017) [7].

Geoindicators are approaches to management and assessment of potential risks to disasters such as in coastal areas. By applying a geo-indicator approach, the coastline can be protected from disaster risk and take appropriate mitigation actions. The method used by collecting data through maps, aerial photographs, videos and documentation of coastal erosion. Evaluate shoreline changes and use natural guidelines to assess hazard risk on the coast by taking a case in Bogue Banks, North Carolina. The use of an approach through Geoindicators can meet disaster risk management on the coast faster and more frequent updates can be made. Field-oriented approaches and periodic oversight by interested local parties are the strength of the Geoindicators approach (Bush et al, 2009) [8].

The low coastline is susceptible to erosion and sealevel rise. Maintenance of beach sand is used to maintain the function of the beach as flood protection, recreation, and biodiversity. This study uses the sand nourishment impact model (N-tool) method for protection against erosion and sea-level rise. Data collection in two study areas namely the Dutch coast and Aveiro coast and using numerical models such as the DELFT3D-WAVE model, coastline evolution model UNIBEST-CL + (Deltares, 2011) and the Nourishment Impact Tool. From the research, it was found that sand nourishment was an effective flood protection method for the Dutch coast. As for Aveiro beach, sand nourishment is feasible for large scale and combined with regulatory policies (Stronkhorsta et al, 2017) [9].

Research by Hakam et al, 2019 [10] on changes in the Padang coastline. Abrasion caused the Padang coastline to retreat more than $50 \mathrm{~m}$. The comparison of coastline changes is only done in the Banjir Kanal area. Groin and jetty development at the mouth of the Banjir Kanal caused the coastline changes. The coastal area on the estuary side has sedimentation. Based on laboratory tests that the grading of sand sediment has the same grain grading as sand 35 years ago.

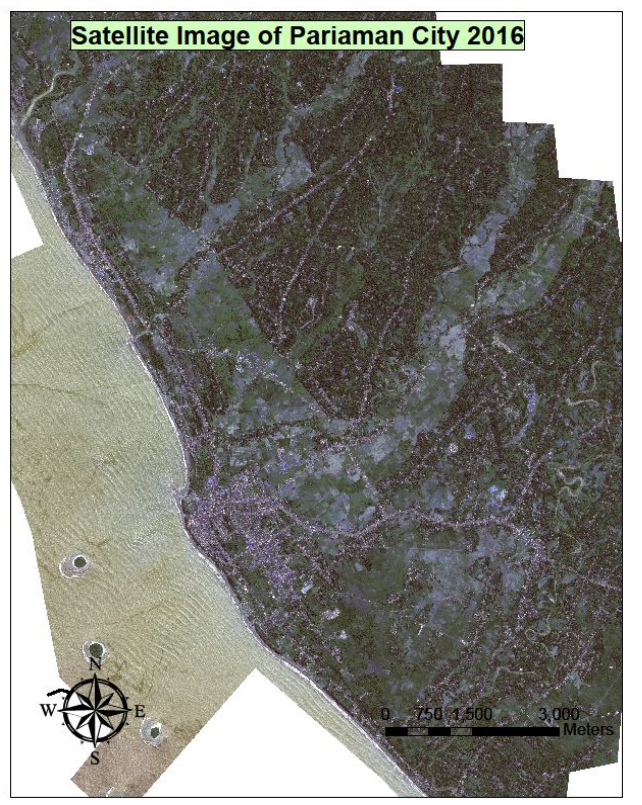

Fig. 1. Pariaman City satellite image

\section{Data and Methodology}

The method to analyzed shoreline changes of Pariaman City by comparing satellite imagery of Pariaman City in
2010 dan satellite imagery in 2016 . The satellite images used are GeoEye-01 satellite images which have been performed orthorectification and accuracy testing by Badan Informasi Geospasial (BIG). 
The method used to monitor shoreline changes using QGIS version 3.8.2. The results of comparing satellite imagery in 2010 and 2016 showed Pariaman City shoreline changes at that time interval. Losses and damage caused by shoreline changes based on field observation in 2015 and 2016.

\section{Pariaman City Shoreline Changes}

Pariaman City has a coastline length up to 15 kilometers. Along the coast, there are four estuaries, Batang Manggung estuary, Batang Pariaman estuary, Batang Jirak estuary, and Batang Mangor estuary. Shoreline changes in Pariaman City divided into five coastal areas, Naras coastal area, Manggung coastal area, Gandoriah coastal area, Kata coastal area, and Sunur coastal area.
Naras is one of the coastal areas of Pariaman City which is changing coastline. In this area, many people use it as a residential area. Erosion is the cause of coastline changes in this area. Erosion occurred along the 1.7 kilometers coastline, with the highest erosion causing the coastline to retreat by 66 meters from 2010 to 2016 .

Manggung coastal areas changed caused by erosion and sedimentation. Erosion occurred on the north side of the Batang Manggung estuary with erosion up to 1 kilometer long. The highest erosion causes the coastline to retreat up to 48 meters. Sedimentation occurred on the southern side of the Batang Manggung estuary with a length of up to 600 meters, with the highest sedimentation reaching 45 meters.
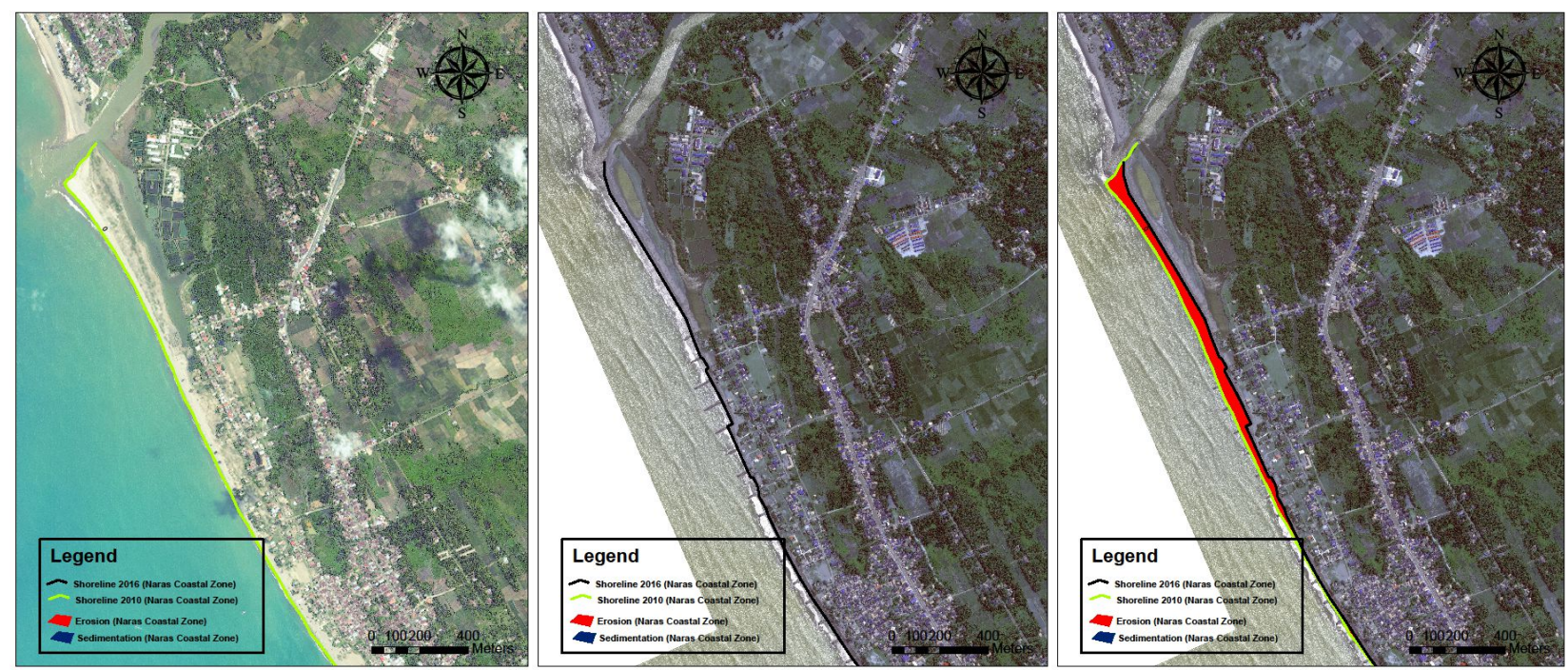

Fig. 2. Naras shoreline changes
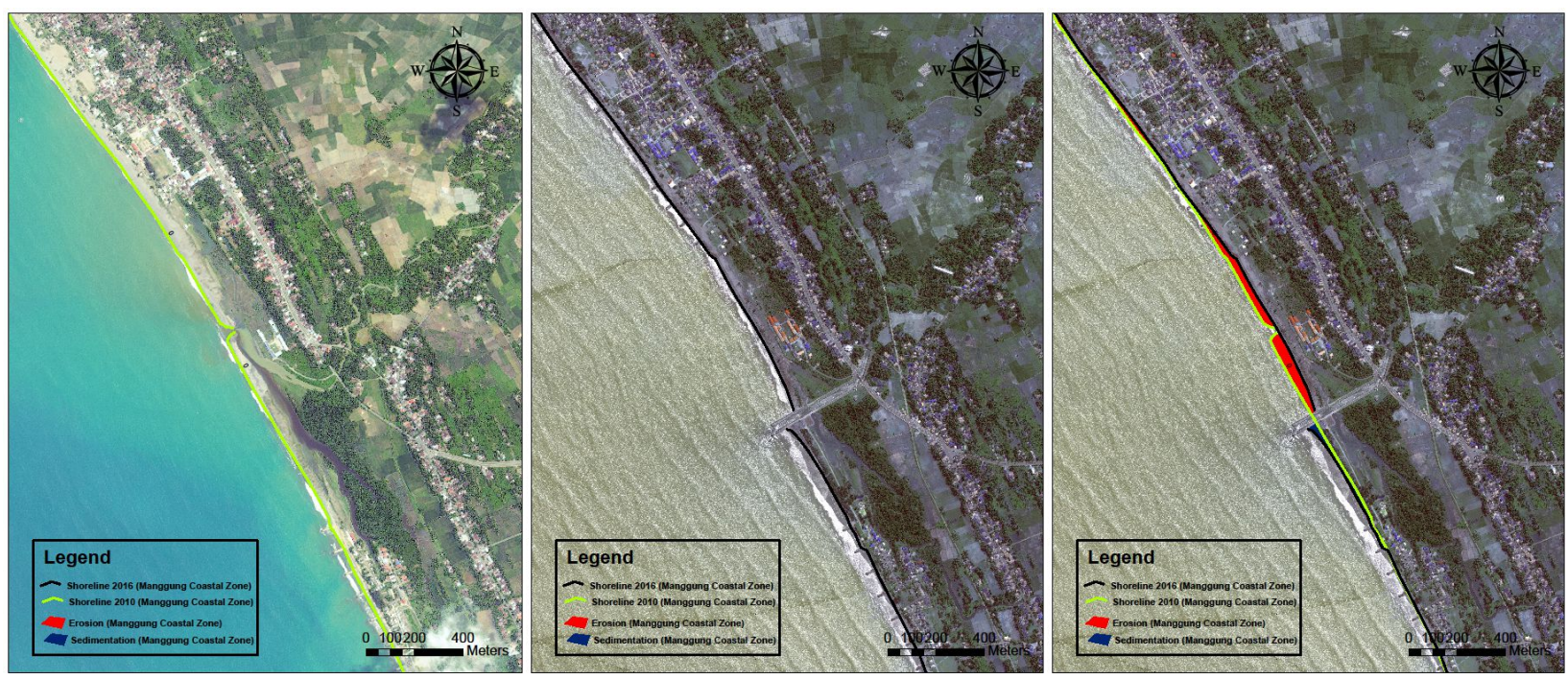

Fig. 3. Manggung shoreline changes 

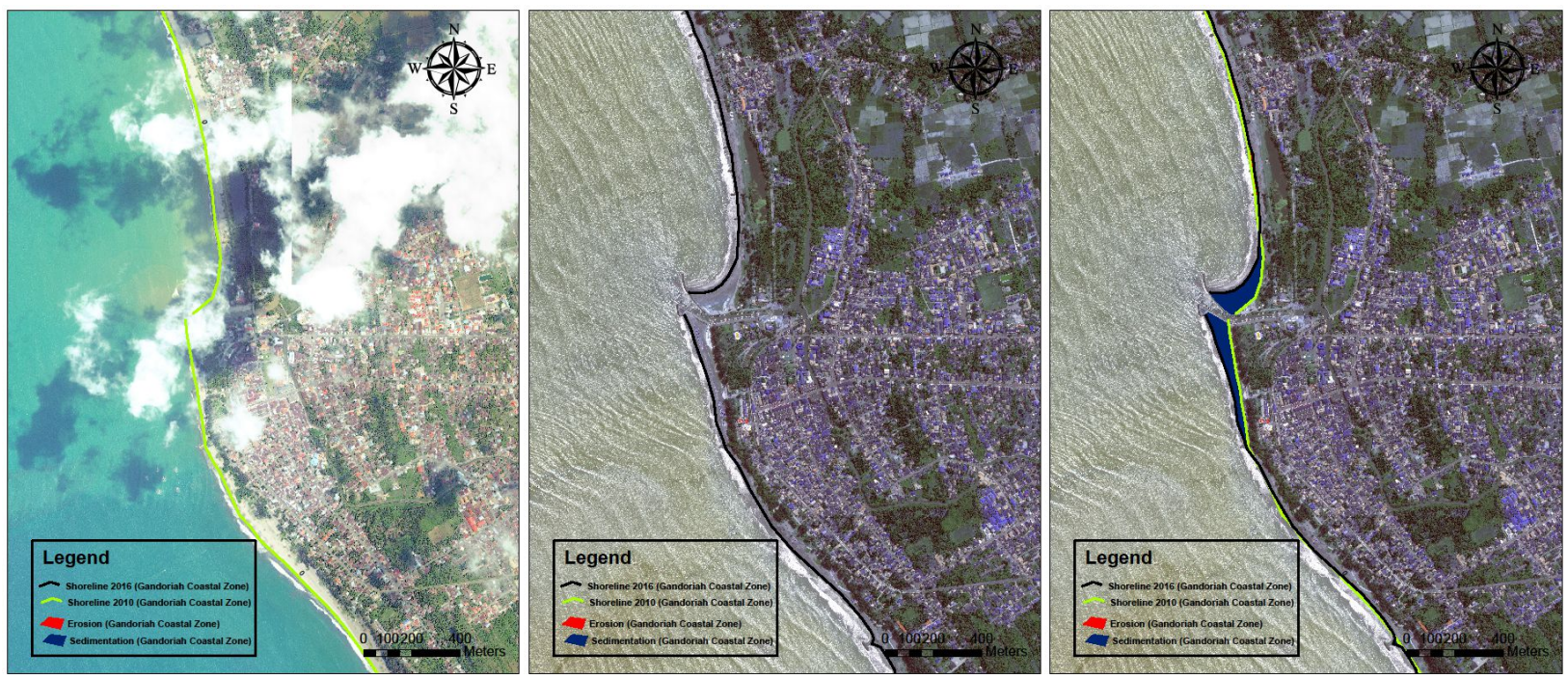

Fig. 4. Gandoriah shoreline changes
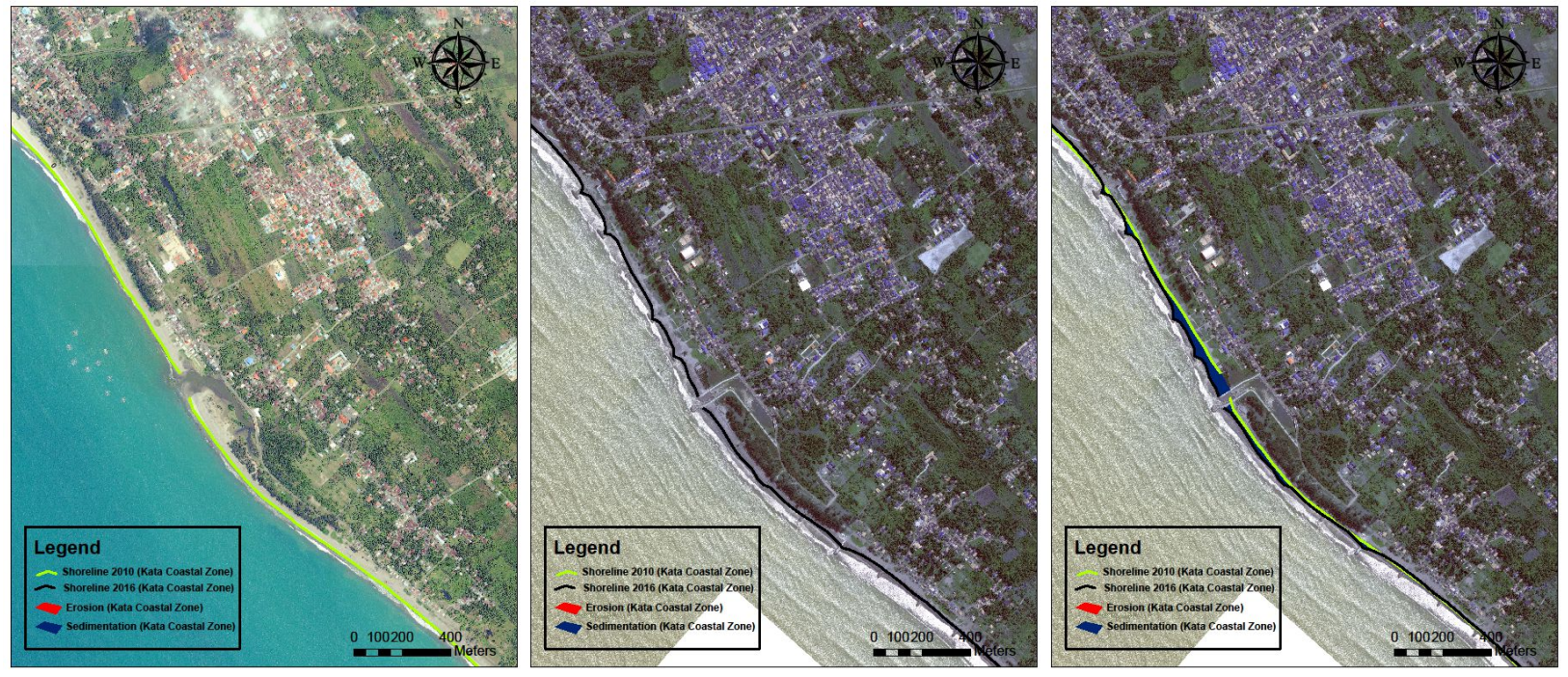

Fig. 5. Kata shoreline changes

Gandoriah coastal area, sedimentation occurred on the north side along 392 meters and the southern side along 551 meters and siltation at the mouth of the Batang Pariaman river.

Shoreline changes that occur in the Kata Beach Area are sedimentation on the north $722 \mathrm{~m}$ and southern sides of the Batang Jirak estuary. Sunur Coastal area sedimentation occurred on the southern side of the Batang Mangor estuary along 632 meters.

\section{Losses and Damage Due to Pariaman City Shoreline Changes}

Pariaman City shoreline changes caused various losses and damage, like the resident's area and public fasilities. Erosion in the Naras coastal area caused damage to residents' homes. Jetties and breakwaters are used to reduce the impact of erosion on the area. Erosion on the Manggung coastal zone if not anticipated will potentially damage the educational facilities in the area. While sedimentation in the mouth of the Batang Pariaman estuary disrupts to ship activities from or towards the estuary. Sedimentation in the Gandoriah coastal area has been used for the construction of tourist facilities or public facilities such as monuments and platforms. So that this facility has the potential to be damaged by waves.

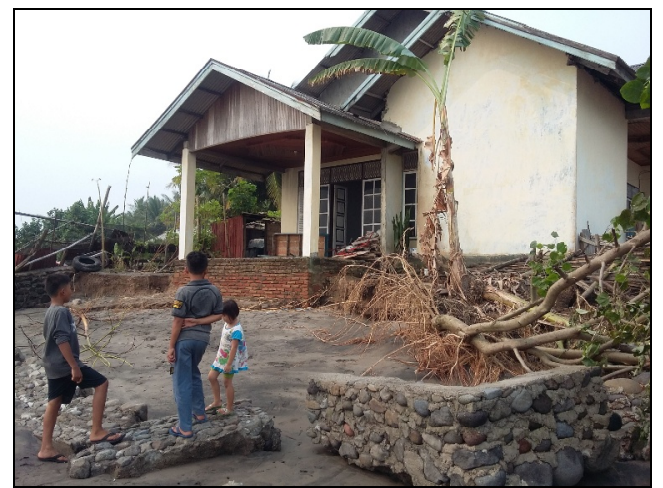

Fig. 6. Shoreline changes damages 

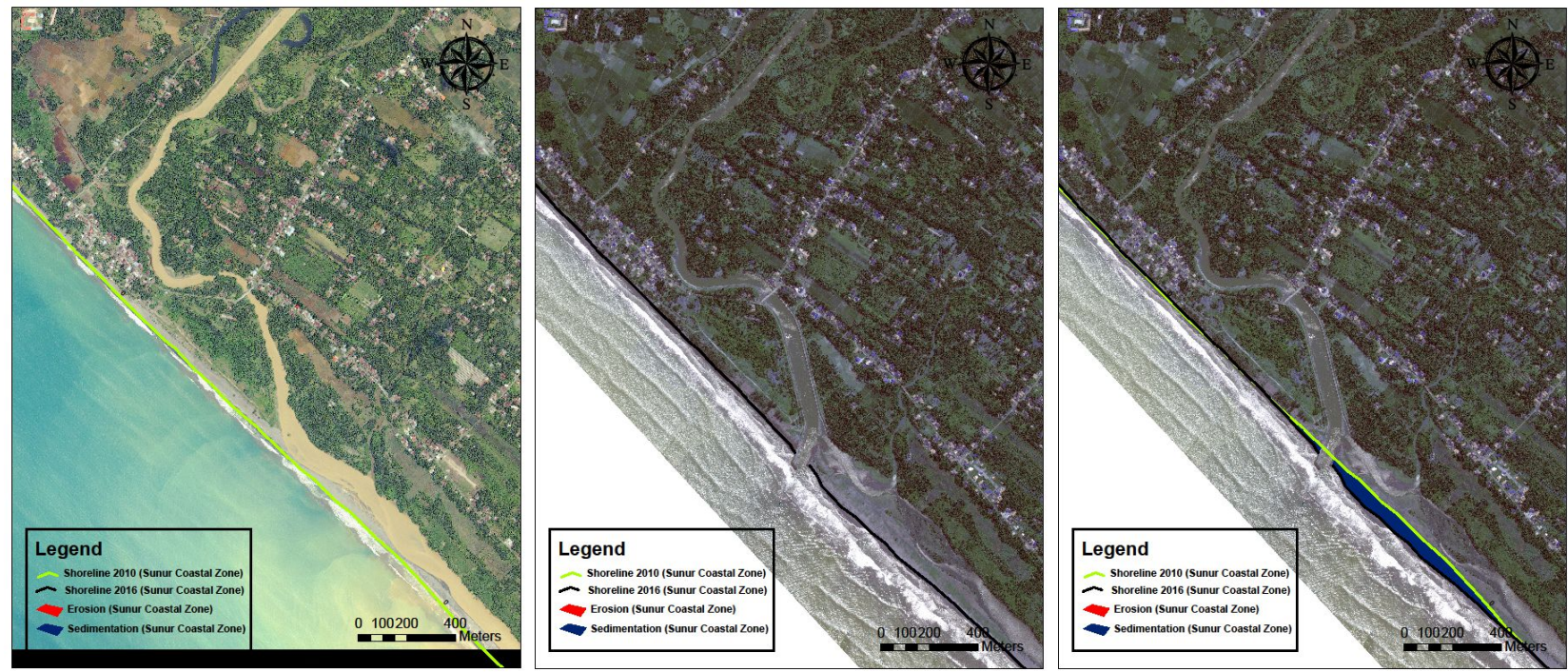

Fig. 7. Sunur shoreline changes
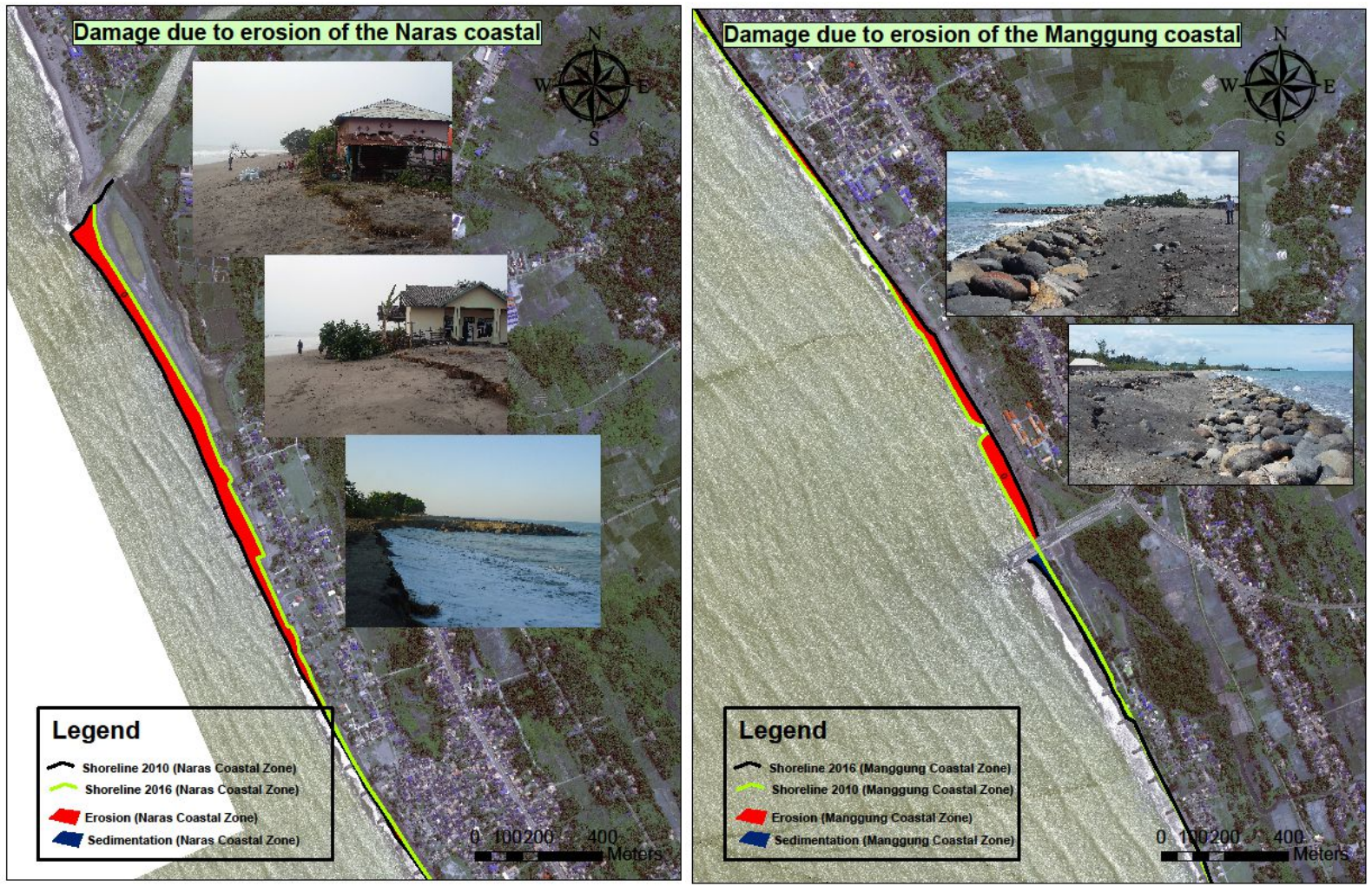

Fig. 8. Losses and damage due to erosion

\section{Conclusions}

Coastal changes in Pariaman City were caused by erosion and sedimentation. Almost all coastal areas of Pariaman City erode. With the highest erosion of $2.7 \mathrm{~km}$ which causes the coastline to retreat reaching 60 meters and $8.26 \mathrm{Km}$ coastlineof Pariaman City retreated about 2-12 meters. Sedimentation occurred in the coastal areas around the estuary of Batang Manggung, Batang Pariaman, Batang Jirak and Batang Mangor.

To reduce the impact of damage and losses caused by coastal changes, it is recommended to the Pariaman City government to conduct an integrated study for the coastal area, formulate regulations to prevent the use of the coastal area as a housing area and carry out the construction of public facilities and tourism facilities in environmentally friendly and friendly coastal areas disaster.

\section{References}

1. Y. Yasumoto, T. Uda, Y. Matsubara dan G. Hiranos, Jurnal Of Coastal Research (ICS2007 (Proceeding), Australia, ISSN 0749.0208) SI 50 82-87, (2007)

2. E.M.T.K. Senevirathna, K.V.D. Edirisooriya, S.P. Uluwaduge, K.B.C.A. Wijerathna, Procedia Engineering 212 1010-1017, (2018) 
3. N. G. Rangel-Buitrago, G. Anfuso, A. T. Williams, Oce. Coast. Mant 114 129-144 (2015)

4. R. S. Kankara, S. Chenthamil Selvan, Vipin J. Markose, B. Rajan, S. Arockiaraj, Procedia Engineering 116855 - 862, (2015)

5. P. Yina, X. Duana, F.Gaoa, M. Lia, S. Lüa, J. Qiua, L. Zhoua, China Geology 4 512-521, (2018)

6. I. Buchori, A. Pramitasari, A.Sugiri, Maryono, Y.Basuki, A. W. Sejati, Oce. Coast. Mant. 163 445455, (2018)
7. A. Williams, N. G. Rangel-Buitrago, E. Pranzini, G. Anfuso, Oce. Coast. Mant. 117 (2017)

8. D.M. Bush, W. J. Neal, R. S. Young, O. H. Pilkey, Oce. Coast. Mant. 42 647-670, (1999)

9. J. Stronkhorsta, B. Huisman, A.Giardino, G. Santinelli, F. D. Santos, Sand Nourishment Oce. Coast. Mant. (2017)

10. A. Hakam, Junaidi, B. M. Adji, Shafira Rahmadilla Hape, Int J GEOMATE 16 170-175, (2019) 